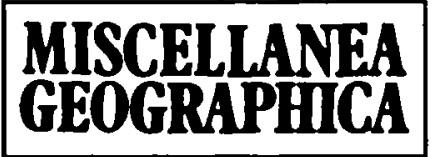

WARSZAWA 1992 Vol. 5

Dobiesław Jędrzejczyk, Waldemar Wilk

\title{
URBANIZATION PROCESSES IN RURAL AREAS OF THE SUBURBAN ZONE OF WARSAW
}

Urbanization of the rural areas has been an inseparable component of industrialization and urbanization of Poland, especially since the end of the Second World War. It chiefly involves transformations of professional structure of rural population and of its subsistence sources. This is particularly intensive in the suburban zones of large agglomerations, such as Warsaw zone of which the nucleus is Poland's capital.

The professional urbanization of the rural area of the suburban zone gives rise to professions unrelated directly to agriculture. It is accompanied by economic urbanization which, in turn, is the process aimed at rational use of rural labour force. On the one hand, the process leads to increase in production and development of services; on the other hand, it results in improvement of the living standard and in putting an end to disproportions between rural and urban areas.

In $1950,43.5$ per cent of people living in rural areas of the Warsaw suburban zone lived on non-agricultural sources. This percentage exceeded nearly twice the country's average ( 22.1 per cent). Coefficients lower than the average were usually found in the western part of the area under investigation and in those which were not situated around towns.

The 1950 National Census revealed that only in three rural communes (out of the total number of 32) of the voivodship (according to the administrative division as of 1 June, 1975) non-agricultural population amounted to less than 20 per cent of total population. Such a typical demographic structure was found in communes on the western outskirts of the region situated around the Kampinos Forest.

The highest percentage of non-agricultural population occurred in 1950 in areas situated chiefly in the direct vicinity of Warsaw. The analysis of their distribution (Fig. 1) leads to the conclusion that those were either communes having common administrative limits with the capital city or situated along the railway lines coming out of Warsaw to the South-West and to the North-East. It was already at that time that in 11 communes (or in over one-third of total number) non-agricultural employment was the main source of support for over half of 


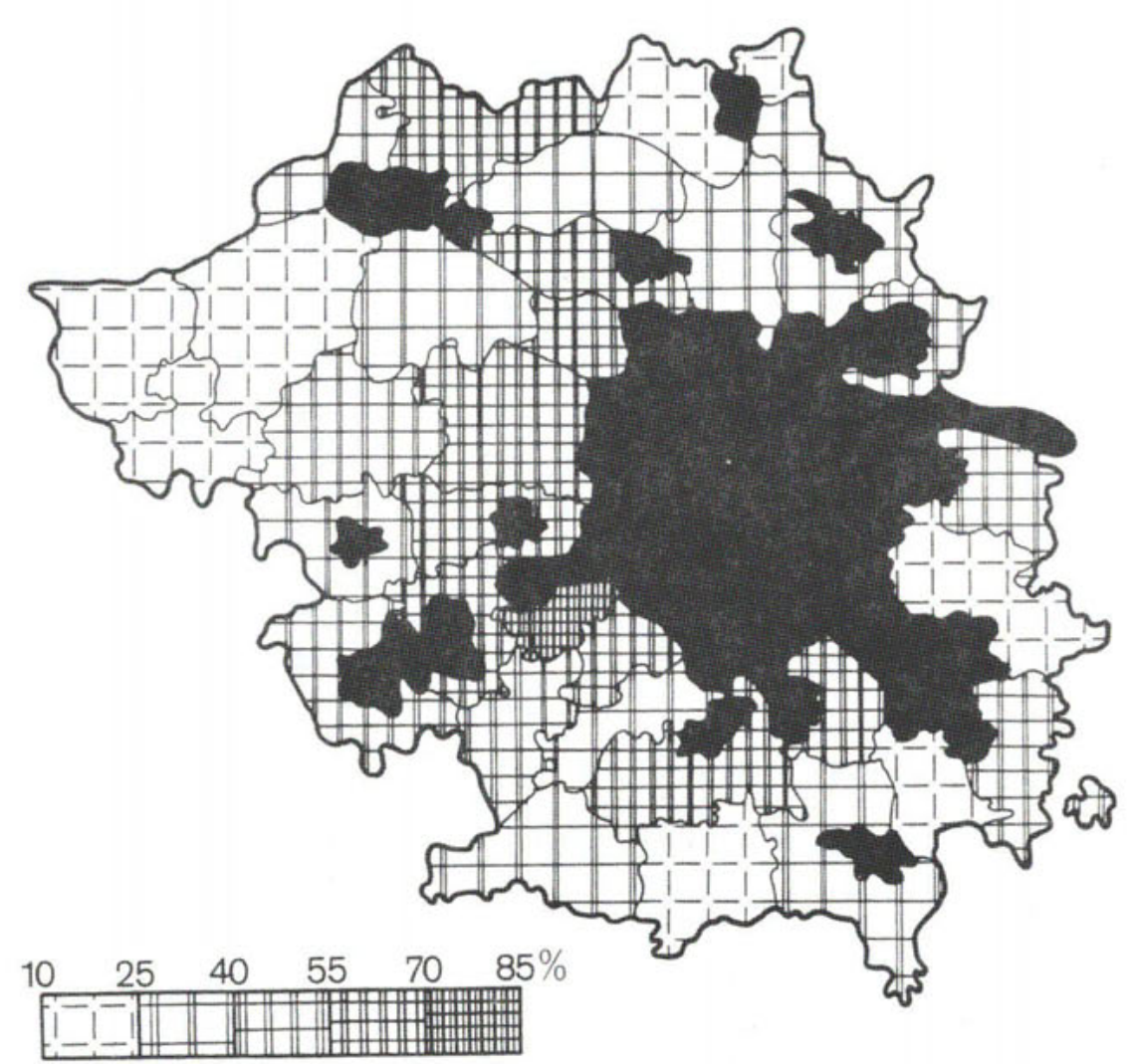

Fig.1. Population living from non-agricultural sources in 1950 (in per cent)

their inhabitants. In the most demographically urbanized communes this index totalled 80 per cent.

The results of the successive censuses revealed a clear increase of the percentage of population earning their living from non-agricultural sources. In the area under research it grew up to 56 per cent in $1960,67.1$ per cent in 1970, 71.6 per cent in 1978, and in 1988 it amounted to 74.7 per cent of people living in rural areas. In 1960, in no commune was this index lower than 20 per cent. Subsequently, a value of 50 per cent was exceeded in 1960 in 18, in 1970 in 27, and in 1978 in 30 out of 32 communes existing in the area under investigation.

In 1988 it turned out that only in one commune more than half of rural population earned their living from agriculture, and in every fourth one more than four-fifths was not employed in agriculture. The relatively least urbanized demographically are still the areas of western and southern parts of the suburban 


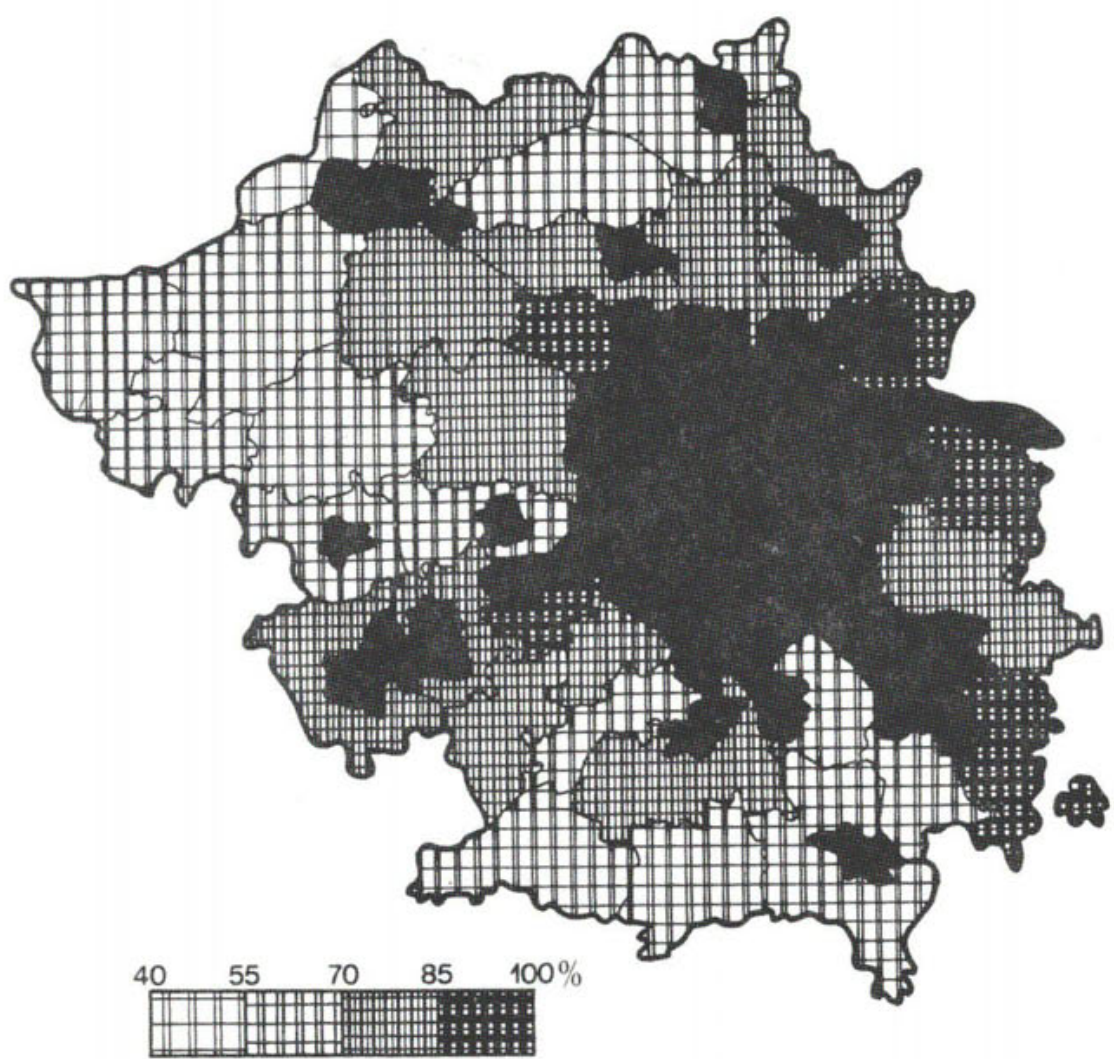

Fig.2. Population living from non-agricultural sources in 1988 (in per cent)

zone of Warsaw (Fig.2). Undoubtedly, the highest indices were recorded in areas adjacent to the capital, and areas situated along transportation routes, chiefly railways (including those of local importance).

In the years 1950-1988, a steady increase of the percentage of rural population living on non-agricultural sources was taking place. It applies both to the average values for the entire suburban zone and to each of the existing villages apart (Fig.3). On the average, this value increased over the area under study by 31.2 points. The particular indices of growth ranged between 9.3 and 54.5.

It should be mentioned that in one case the growth amounted only to 1.9 points. However, the administrative limits of this commune were considerably changed which could influence the value of the index. The index dropped also in some other communes in the period between the censuses. However, these drops have always been accompanied by changes of administrative limits, chiefly annexations of rural areas within the city limits. 


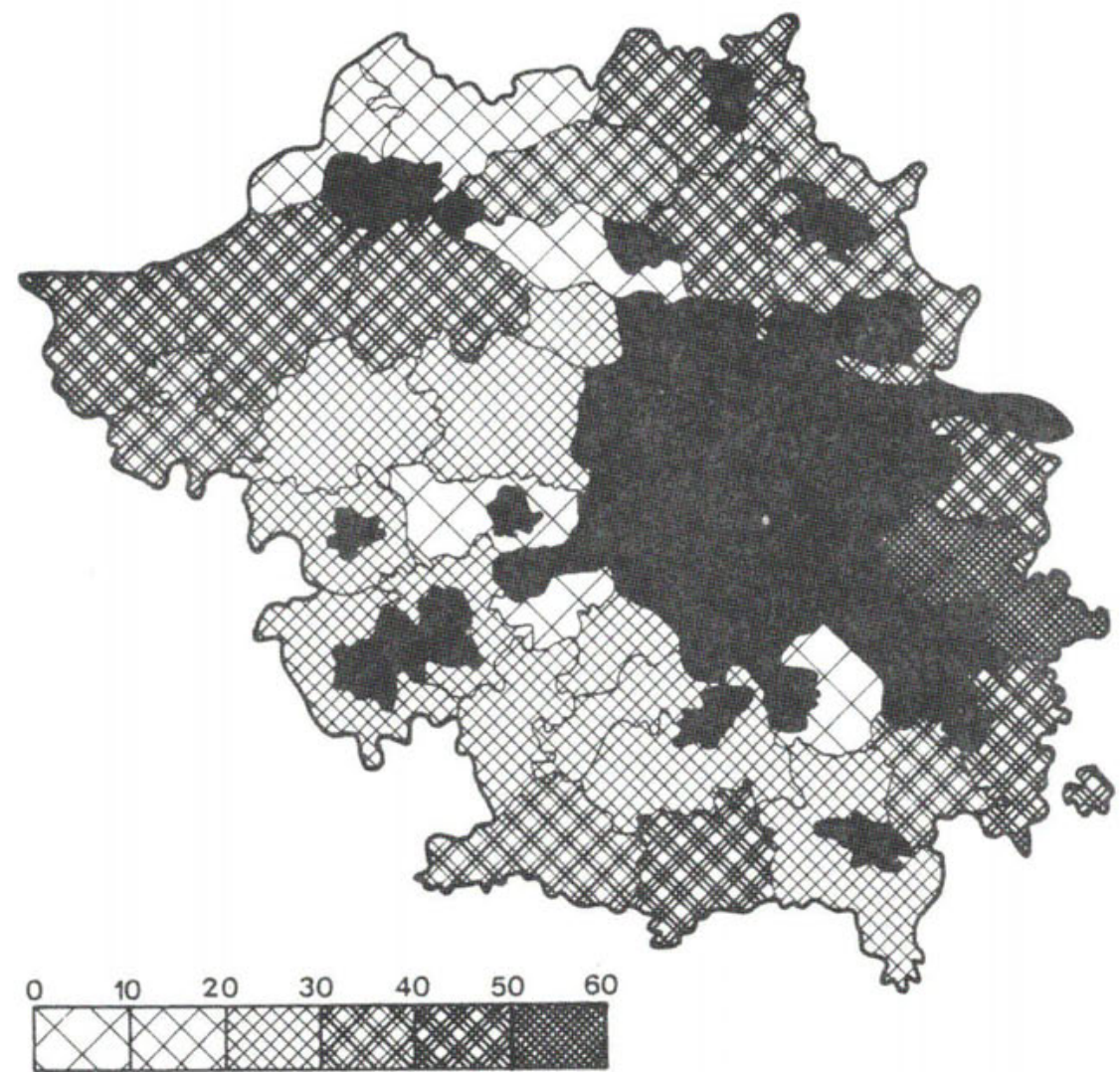
1988

Fig.3. Change in percentage of population living from non-agricultural sources in the years 1950 -

Generally speaking, the highest increase of the percentage of non-agricultural population was recorded in the rural areas situated to the North and South-West of Warsaw, as well on the western periphery of the zone. The index slightly increased in the areas adjacent to the capital city. These areas, however, were urbanized to a considerable extent already at the beginning of the period (1950). In 1988 , the percentage of non-agricultural population in these rural areas was approximate to indices reached by towns situated in this zone.

In the suburban zone of Warsaw, the acceleration of socio-economic development of rural areas is due to the taking up of non-agricultural work by rural population. Warsaw plays the role of a growth pole surrounded by an urban field described by the models of J. Fiedmann and J. Miller (1965). 
Professional urbanization of population of the rural suburban zone of Warsaw brings diverse effects. In the first place, it leads to a decreasing number of people employed in agriculture and to differentiation of the traditional rural structures. The latter phenomenon is taking place through the establishment of spatial links of diverse intensity and dynamics of change. In effect, it leads to obliteration of the basic differences in the lifestyles between the urban and rural areas.

\section{REFERENCES}

Fri ed m a n J., M ill e r J., 1965, "Urban Field", Journal of the American Institute of Planners, Vol.29, No.4, pp.312-319.

Rakowski W., 1975, "Procesy urbanizacji wsi (na przykładzie województwa warszawskiego)" (Processes of rural urbanization. A case study of the Warsaw voivodship), Studia KPZK PAN, Vol.I.

Stasiak A., 1977, "Przemiany w strukturze zawodowej wsi w Polsce" (Transformations in professional structure in rural areas in Poland), Przeglad Geograficzny, Vol.XLIX, No.4.

Zi ólkows ki J., 1965, Urbanizacja, Miasto, Osiedle (Urbanization: town and settlement), Warszawa. 
